\title{
OPEN Early Cretaceous sea surface temperature evolution in subtropical shallow seas
}

\author{
Stefan Huck ${ }^{\bowtie}$ \& Ulich Heimhofer
}

Late Cretaceous sea surface temperatures (SST) are, amongst others, traditionally reconstructed by compiling oxygen isotope records of planktonic foraminifera obtained from globally distributed pelagic IODP drill cores. In contrast, the evolution of Early Cretaceous SSTs is essentially based on the organic TEX ${ }_{86}$ palaeothermometer, as oxygen-isotope data derived from well-preserved 'glassy' foraminifer calcite are currently lacking. In order to evaluate the extraordinary warm TEX $_{86}$-derived SSTs of the Barremian to Aptian (130-123 Ma) subtropics, we present highly resolved sclerochemical profiles of pristine rudist bivalve shells from Tethyan and proto-North Atlantic shallow water carbonate platforms. An inverse correlation of seasonal ontogenetic variations in $\delta^{18} \mathrm{O}_{\text {rudist }}$ and $\mathrm{Mg} / \mathrm{Ca}$ ratios demonstrates the fidelity of oxygen isotopes as palaeotemperature proxy. The new data shows moderate mean annual SSTs $\left(22-26^{\circ} \mathrm{C}\right)$ for large parts of the Barremian and Aptian and transient warm pulses for the so-called Mid-Barremian Event and Oceanic Anoxic Event 1a (reaching mean annual SSTs of 28 to $\left.30^{\circ} \mathrm{C}\right)$. A positive shift in mean annual oxygen-isotope values $\left(\delta^{18} \mathrm{O}: \leq-0.3 \%\right.$ ) coupled with invariant $\mathrm{Mg} / \mathrm{Ca}$ ratios at the Barremian-Aptian boundary points to a significant net loss of ${ }^{16} \mathrm{O}$ in Tethyan shallow-marine settings. As the positive oxygen-isotope rudist shell values are recorded immediately beneath a major superregional hiatal surface, they are interpreted to be related to a major cooling phase and potential glacio-eustatic sea-level lowering. Our new sclerochemical findings are in clear contrast to open ocean SST records based on TEX ${ }_{86}$, which indicate exceptionally warm Barremian to earliest Aptian subtropical oceans and weak meridional SST gradients.

The study of past greenhouse climates such as the Cretaceous provides fundamental insights into Earth's response to increased concentrations of greenhouse gases. In this context, proxy data-based paleoenvironmental reconstructions play a central role in evaluating the ability of climate models to simulate past, present and future climate change ${ }^{1}$. In particular, the assessment of stratigraphically well-constrained high-resolution temperature (and $\mathrm{CO}_{2}$ ) proxy records is paramount for a better understanding of the potential range and rate of future climate change ${ }^{2}$.

The Cretaceous climate is generally described as a warm to hot greenhouse world characterized by high atmospheric $\mathrm{CO}_{2}$ levels and weak equator-to-pole thermal gradients (e.g., $\left.{ }^{3,4}\right)$. The Early Cretaceous climatic warming culminated in the Cenomanian-Turonian Thermal Maximum and was followed by a gradual long-term cooling trend towards the Early Maastrichtian 'cool' greenhouse (e.g., ${ }^{5-7}$ ). The stability of the greenhouse climate has long been questioned by a variety of sedimentological, palaeontological, geochemical, sequence stratigraphic and modelling data. In fact, there is abundant evidence for the existence of Cretaceous 'cold snaps' or the potential transient occurrence of polar ice sheets (e.g. $\left.{ }^{8-16}\right)$.

One of the most important diagnostic features for earth' climate state and its variability (in deep time) is sea surface temperature (SST). Reconstructions of Cretaceous open ocean SSTs are predominantly based either on crenarchaeotal membrane lipid distributions (isoGDGTs) from pelagic deposits (referred to as $\mathrm{TEX}_{86}$ proxy) or on oxygen isotope compositions recorded in low-Mg calcite hard parts of planktonic foraminifers,6,7,16-22. Late Cretaceous oxygen isotope and $\mathrm{TEX}_{86}$ SST records provided by ocean drilling campaigns are usually highly resolved and stratigraphically well-calibrated, which (1) provides a very detailed record of SST change with time across paleolatitude and (2) allows for a comparison with deep-sea $\delta^{18} \mathrm{O}$ trends as recorded in benthic foraminiferal calcite ${ }^{5}$. In contrast, Early Cretaceous pelagic deposits lack well-preserved (glassy) planktonic foraminifer tests, which in turn hampers any critical evaluation of the extraordinary warm Early Cretaceous TEX ${ }_{86}$ SSTs $\left(>35^{\circ} \mathrm{C}\right)^{6}$. Alternative substrates for oxygen isotope palaeothermometry are the calcitic guards of belemnites ${ }^{23,24}$. 

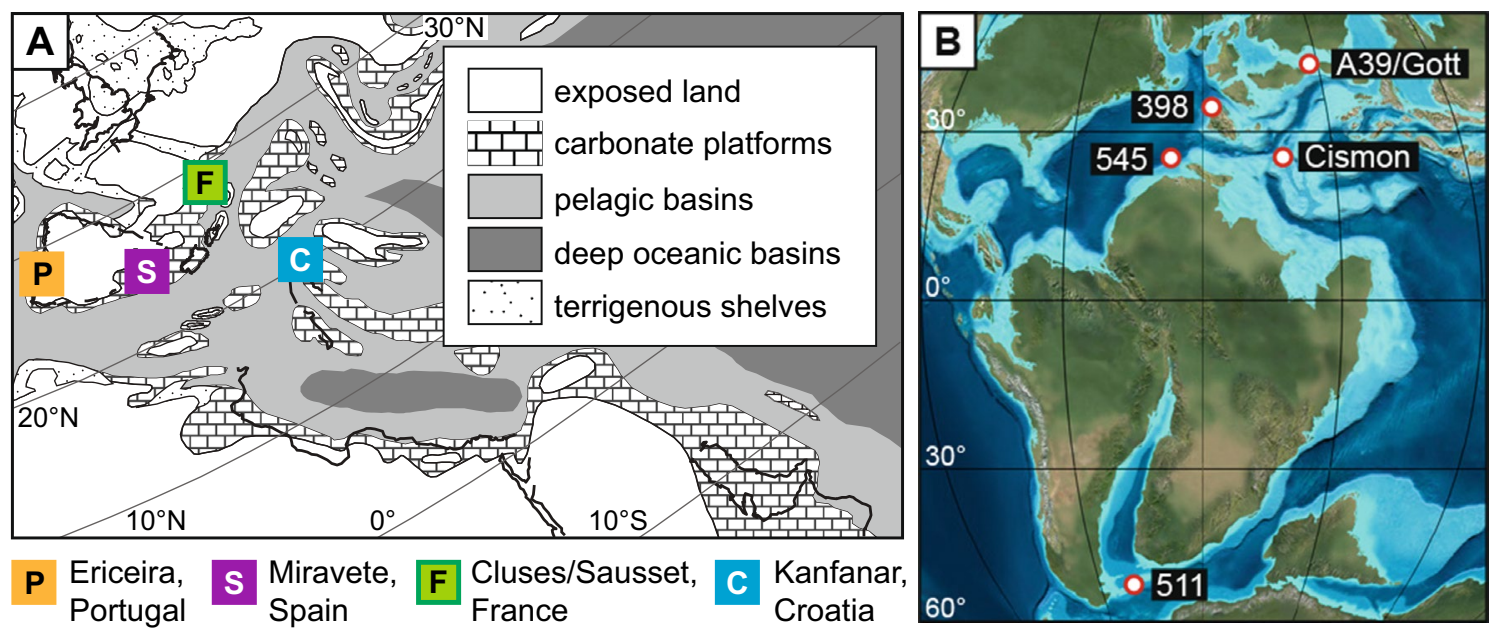

Figure 1. (A) Early Aptian paleogeography of the Atlantic-Tethyan realm with localities of considered study sites in Portugal (Ericeira), Spain (Miravete), France (Sausset and Cluses) and Croatia (Kanfanar section). Map modified after Steuber et al. ${ }^{27}$. (B) Aptian paleogeography of the Tethyan and proto-North-Atlantic realm with locations of considered pelagic sections and oceanic drill sites. Map modified from R. Blakey, https://deept imemaps.com/.

Due to the nektonic lifestyle of these squid-like organisms, however, belemnite-based SST records are likely influenced by differences in habitat depths ranging from $200 \mathrm{~m}$ towards the sea surface ${ }^{25}$.

Complementary to pelagic proxy records, rudist bivalve shells have been proven as suitable shallow marine neritic SST archive ${ }^{26-28}$. Their thick low-Mg calcite shells allow for a quantitative assessment of ontogenetic oxygen isotope and $\mathrm{Mg} / \mathrm{Ca}$ variations at a sub-annual (seasonal) resolution ${ }^{29,30}$-referred to as chemical sclerochronology ${ }^{31}$.

A SST dataset covering pre-Albian times with a similar stratigraphic precision to pelagic $\mathrm{TEX}_{86}$ records is currently not available. Therefore, high-resolution chemical sclerochronology $\left(\delta^{18} \mathrm{O}, \mathrm{Mg} / \mathrm{Ca}, \mathrm{Sr} / \mathrm{Ca}\right)$ has been performed on pristine (i.e., compact and fibrous, and chemostratigraphically well-constrained) rudist shells collected from subtropical Barremian-Aptian shallow-marine carbonate platform sections. The overall aim is to (1) reconstruct the Barremian-Aptian evolution of subtropical mean annual SSTs as well as their seasonal variability. Of particular interest is (2) the contrast comparison of rudist shell-derived SST estimates with existing $\mathrm{TEX}_{86}$ as well as belemnite $\delta^{18} \mathrm{O}$ compilations and the (3) detection of climate extremes (hyperthermals, cold snaps) within the greenhouse state.

\section{Palaeogeographic and palaeoenvironmental setting}

Rudist bivalves were collected from five Barremian to Aptian carbonate platform sections (Fig. 1A; Ericeira, Portugal $=$ P, Miravete, Spain $=$ S, Sausset and Cluses, France $=$ F, Kanfanar, Croatia $=$ C) representing subtropical Tethyan and proto-North Atlantic shallow water settings between $23^{\circ}$ and $32^{\circ} \mathrm{N}$. Paleolatitude estimates of the different localities are based on van Hinsbergen et al. ${ }^{32}$.

Rudists belong to the sessile benthos and all studied taxa (Requienidae, Polyconitidae, Monopleuridea) are considered to have inhabited an inner carbonate platform domain with negligible meteoric influence ${ }^{33}$. The pristine preservation state of all analyzed shells is proven by means of elemental and stable isotope properties (see SI Appendix Dataset S1) and subordinately cathodoluminescence characteristics ${ }^{34,35}$. Age assignments of shells are based on an integrated carbon and strontium isotope stratigraphic framework (Fig. 3: ${ }^{34-37}$; see "Material and methods" section).

\section{Results}

Most shells record cyclic, often sinusoidal oxygen-isotope variations with peak-to peak amplitudes ranging between 1.6 and 3.1\%o (Figs. 2A, 3, see also SI Appendix, Figures S1-S3 and Dataset S1 for detailed results). Annual growth rates depicted by the wave-lengths of these (seasonal) $\delta^{18} \mathrm{O}$ cycles vary from 2 to $6 \mathrm{~cm}$.

Rudists from the Provence and Jura-Bas-Dauphiné platforms in SE France (Sausset/Cluses: $29^{\circ}-32^{\circ} \mathrm{N}$ ) provide sclerochronological mean oxygen isotope $\left(\delta^{18} \mathrm{O}_{\text {sclero }}\right)$ values ranging between - 3.9 (uppermost Lower Barremian) and $-0.3 \%$ o (lowermost Lower Aptian). The majority of upper Barremian $\delta^{18} \mathrm{O}_{\text {sclero }}$ values from the Provence cluster around a value of $-2.1 \%$. Lower Aptian (pre-OAE1a) rudists inhabiting both proto-Atlantic (Ericeira: $27^{\circ} \mathrm{N}$ ) and Tethyan (Kanfanar: $23^{\circ} \mathrm{N}$ ) shallow-water settings show $\delta^{18} \mathrm{O}_{\text {sclero }}$ values near to $-3.4 \%$. At Kanfanar, rudist shell material ascribed to the onset of OAE1a (chemostratigraphic segment C4) ${ }^{38}$ provides a $\delta^{18} \mathrm{O}_{\text {sclero }}$ value of $-2.6 \%$. Slightly lower $\delta^{18} \mathrm{O}_{\text {sclero }}$ values $(-2.8 \%$ ) characterize post-OAE1a rudist shells from E Spain (Miravete: $26^{\circ} \mathrm{N}$ ).

Shells are characterized by low Fe (mean: 43 ppm; s.d.: 40 ppm) and Mn contents (mean: 3 ppm; s.d.: 7 ppm) and high Sr contents (mean: 1140 ppm; s.d.: 122 ppm). Detailed element compositions (ppm) and magnesium/ calcium ratios are presented in SI Appendix, Dataset S1. Here, we only report on $\mathrm{Mg} / \mathrm{Ca}$ molar ratios, which 
A
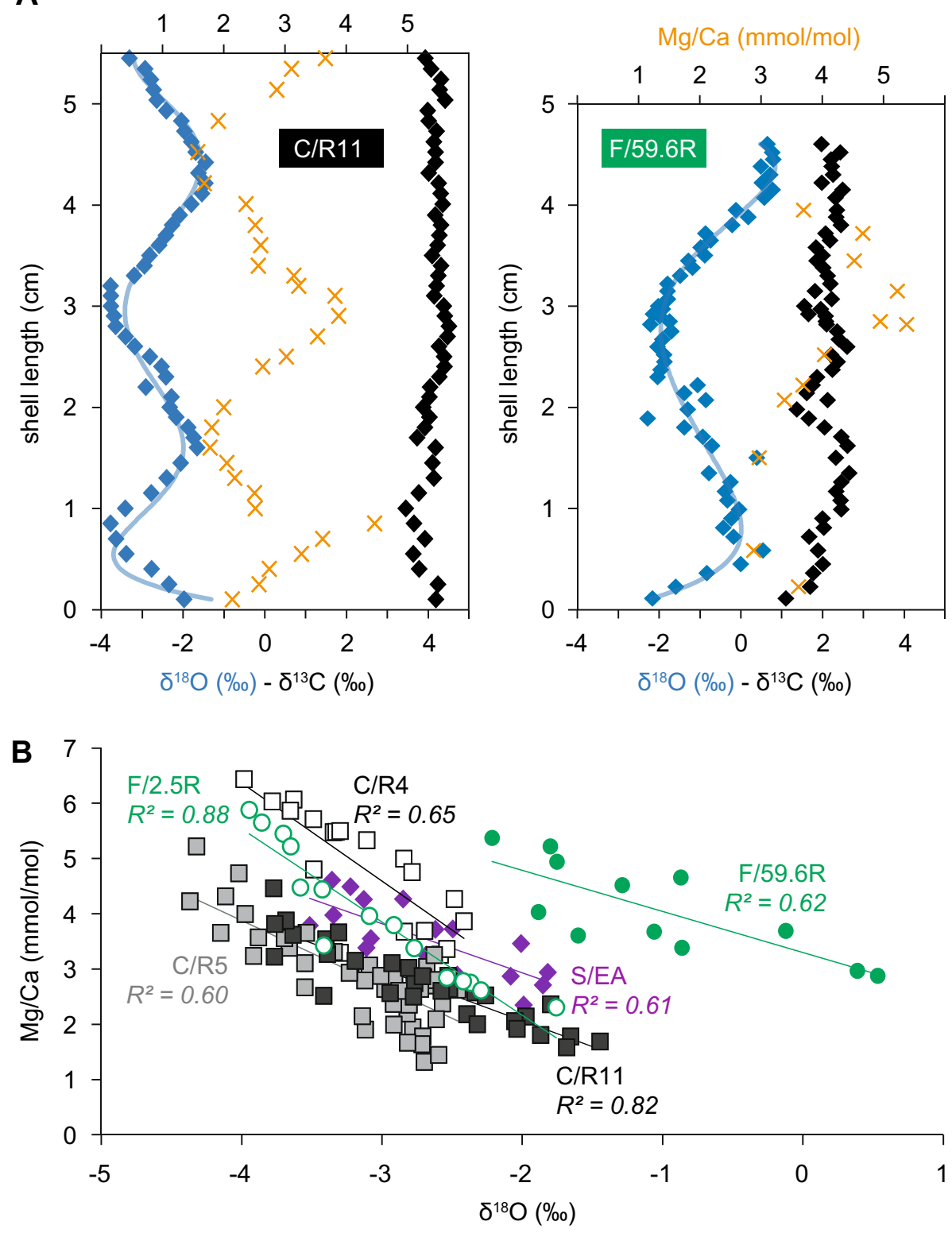

Figure 2. (A) Sclerochemical results $\left(\delta^{18} \mathrm{O}, \delta^{13} \mathrm{C}, \mathrm{Mg} / \mathrm{Ca}\right)$ of selected rudist shells from Croatia $(\mathrm{C} / \mathrm{R} 11)$ and France (F-59.6R). Blue lines represent polynomial trendlines. (B) Cross-plot of $\delta^{18} \mathrm{O}_{\text {rudist }}$ and $\mathrm{Mg} / \mathrm{Ca}$ molar ratios selected rudist shells from France (F/2.5; F/59.6), Croatia (C/R4; C/R5; C/R11) and Spain (S/EA).

are-at least in a qualitative manner-assumed to be linked to sea surface temperature ${ }^{39}$. Mean $\mathrm{Mg} / \mathrm{Ca}$ ratios of sclerochronological shell transects range between $2.7(\mathrm{C} / \mathrm{R} 11)$ and $4.9(\mathrm{C} / \mathrm{R} 4)$. All analyzed shells provide evidence for a cyclic $\mathrm{Mg} / \mathrm{Ca}$ pattern, with peak-to-peak amplitudes varying from 2.5 (sample F/59.6R; Fig. 2A) to 3.6 (sample F/2.5R). Mg/Ca cycles are very well anti-correlated with oxygen-isotope cycles (e.g., S/EA: $r=-0.78$; $p<0.001 ; \mathrm{C} / \mathrm{R} 11: \mathrm{r}=-0.91 ; p<0.001$ ) (Fig. 2B and SI Appendix, Dataset S1).

\section{Discussion}

Fidelity of rudist shell elemental and stable isotope compositions. Polished slabs document the pristine preservation state of analyzed rudist shells by the occurrence of low-Mg calcite fibers arranged in welldistinguishable growth increments (SI Appendix, Figures S1 and S3). Measured elemental (Mg, Sr, Fe, Mn) and isotope compositions $\left(\delta^{18} \mathrm{O}, \delta^{13} \mathrm{C}\right)$ overlap very well with those assessed from diagenetically screened Cretaceous rudist shells collected from similar latitudinal settings ${ }^{29} \cdot{ }^{87} \mathrm{Sr} /{ }^{86} \mathrm{Sr}$ values (Fig. 3) are in excellent agreement with Barremian-Aptian marine strontium-isotope compilations ${ }^{40}$. The fidelity of both, stable isotope and elemental shell data is emphasized by a cyclic sclerochronological pattern of both oxygen-isotope and $\mathrm{Mg} / \mathrm{Ca}$ molar ratios (Fig. 2A). Only few stable isotope outliers escaped the diagenetic screening protocol. 
A

${ }^{13} \mathrm{C}(\%)$

B

C

recent tropical SSTs

$\left(0-23.5^{\circ} \mathrm{N}\right)$
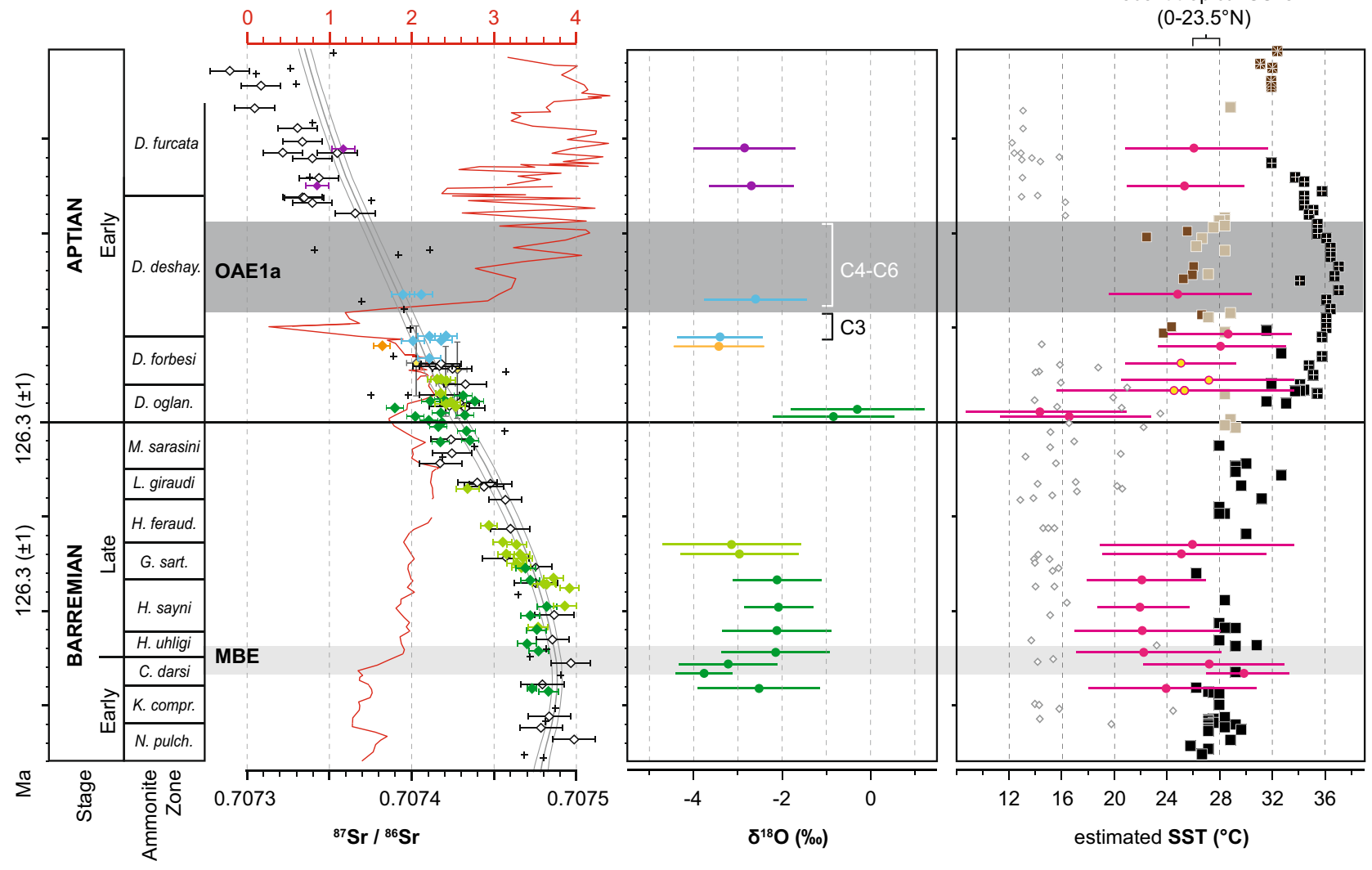

strontium isotope stratigraphy

$\longmapsto 2 \sigma$ mean

paleothermometry

$\longrightarrow$ annual mean + seasonal range

\section{rudist shells}

Sausset $(F)$ Kanfanar $(C)$

Cluses (F) Ericeira (P) $\diamond$ Steuber et al. (2005)

\section{belemnites various substrates \\ $\diamond$ Bodin et al. (2015) + McArthur et al. (2001)}

carbon isotope stratigraphy

— Godet et al. (2006); Westermann et al. (2013)

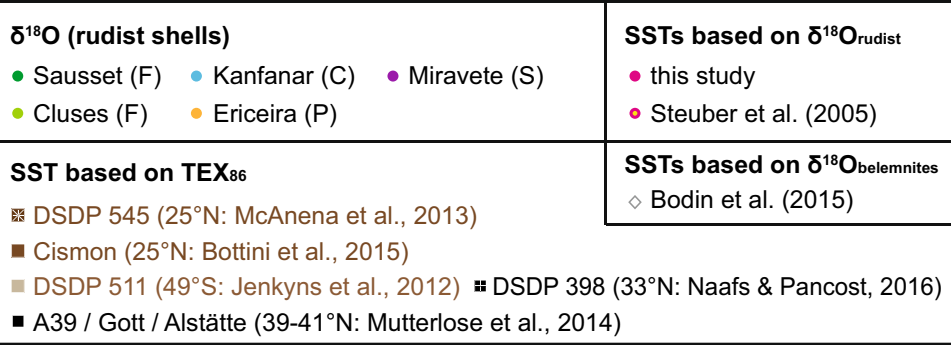

Figure 3. (A) Evolution of Barremian-Aptian global marine ${ }^{87} \mathrm{Sr} /{ }^{86} \mathrm{Sr}$ and carbon-isotope ratios compiled from previous work on pelagic carbonate bulk and low-Mg calcite fossils (belemnites, bivalves). (B) Oxygen isotope sclerochronology of selected rudist shells-this study. (C) Sea surface temperature (SST) estimates based on oxygen isotope palaeothermometry (belemnites, rudists) and $\mathrm{TEX}_{86}$. Note that rudist sclerochronology also provides information on the seasonal range of SSTs. All results are calibrated to the GTS 2012 timescale $^{75}$. See figure for references.

Observed asymmetric $\delta^{18} \mathrm{O}$ cycles typically reflect variable intra-annual shell growth rates, i.e. relatively enhanced growth rates during the colder seasons (e.g., sample C/R1: SI Appendix, Dataset S1). Occasionally occurring saw-tooth shaped peaks (e.g., sample F/62.3R: SI Appendix, Dataset S1) indicate growth cessations associated with seasonal (here: cool) SST extremes ${ }^{41,42}$. A well-expressed anti-correlation of $\delta^{18} \mathrm{O}$ and $\mathrm{Mg} / \mathrm{Ca}$ molar ratios (Fig. 2B) corroborates the application of oxygen isotopes as palaeotemperature proxy, although a multitude of studies (e.g., 43) on recent and fossil bivalves provide evidence that other factors (e.g., metabolic activity, growth rate, ontogenetic age) influencing the $\mathrm{Mg} / \mathrm{Ca}$ molar ratio of individual shells have to be considered. The observation of different slopes of $\delta^{18} \mathrm{O}-\mathrm{Mg} / \mathrm{Ca}$ regression lines (Fig. 2B, see also SI Appendix, Figure S4), provided by different taxa (Toucasia carinata, Requienia zlatarskii: C-R4 and C-R5) collected from the same stratigraphic level, demonstrates a species-specific biological control on recorded $\mathrm{Mg} / \mathrm{Ca}$ ratios $^{30,43}$.

Barremian-Aptian neritic SST evolution. Rudist shell $\delta^{18} \mathrm{O}$ values provide evidence for a transient $(<400 \mathrm{kyr})$ warming pulse $\left(27-30^{\circ} \mathrm{C}\right)$ associated with the Mid-Barremian Event (MBE; Coronites darsi ammonite zone $)^{35}$. In the Tethyan Ocean, the MBE is characterized by a $0.5 \%$ positive carbon-isotope shift and the onset of black-shale deposition ${ }^{44}$. Low-Mg calcite belemnite guards from the boreal realm (A39 and Gott sections: Fig. 1B) document a similar climatic scenario (SST increase from $16^{\circ} \mathrm{C}$ towards $20^{\circ} \mathrm{C}$ ), which is referred 
to as Aulacoteuthis warm pulse ${ }^{45}$. Belemnites from the Vocontian Basin, in contrast, do not provide evidence for a pronounced negative oxygen isotope excursion during the $\mathrm{MBE}^{46}$. There, Barremian transient negative $\delta^{18} \mathrm{O}$ shifts in belemnite calcite in the prelude and aftermath of MBE were proposed to be caused by the impact of meteoric water ${ }^{46}$. The circum-Vocontian rudist-bearing carbonate platform sections studied here (Sausset, Cluses: ${ }^{34,35}$ ), however, do not provide any paleobiological evidence (e.g., reduced biodiversity, lack of stenohaline organisms or spread of charophyceans or microbial mats) for a significant salinity reduction (7-8 PSU considering a $1.3-1.6 \% \delta^{18} \mathrm{O}_{\text {sw }}$ change) due to freshwater inflow ${ }^{29,47}$.

Relatively temperate climatic conditions with mean annual SSTs of about $22{ }^{\circ} \mathrm{C}$ prevail during the early Late Barremian (Hyperaspis uhligi and Heinzia sayni ammonite zones), followed by a mid-Late Barremian SST rise towards $26^{\circ} \mathrm{C}$ (Gerhardtia sartousiana ammonite zone) (Fig. 3). Upper Barremian belemnites both from the boreal and Tethyan realms document relatively cool temperatures ${ }^{46}$, which are significantly lower $\left(14-16^{\circ} \mathrm{C}\right)$ than seasonal SST minima $\left(17-19^{\circ} \mathrm{C}\right)$ of contemporaneous rudist shells. As mentioned earlier, this difference is likely explained by differences in habitat depth ${ }^{25}$. Remarkably cool mean annual SSTs $\left(14\right.$ and $\left.16^{\circ} \mathrm{C}\right)$ are derived from lowermost Aptian rudist shells (Deshayesites oglanlensis ammonite zone). Additional proxy-based evidence for a transient earliest Aptian episode of climatic cooling comes from fish teeth apatite palaeothermometry (amplitude: $\left.4-6^{\circ} \mathrm{C}\right)^{48}$. Strongly declining rudist shell oxygen isotope values in the prelude of the Early Aptian OAE1a provide evidence for rapid climatic warming, reaching maximum mean annual SSTs of about $28^{\circ} \mathrm{C}$ at the onset of the event (Deshayesites forbesi ammonite zone, chemostratigraphic segment $\mathrm{C} 3 \mathrm{of}^{38}$ ). During OAE1a (chemostratigraphic segment C4: Deshayesites deshayesi ammonite zone) rudist mean annual SSTs decline by about $3{ }^{\circ} \mathrm{C}$ (Fig. 3). This cooling episode has been previously noticed by a high-resolution oxygen-isotope study carried out on well-preserved pelagic nannofossil-rich carbonate bulk material ${ }^{49}$ and is compatible with an atmospheric drawdown of $\mathrm{CO}_{2}$ due to enhanced organic carbon burial and silicate weathering ${ }^{50}$. In the aftermath of OAE1a (Deshayesites furcata ammonite zone), rudist shell mean annual SSTs prevail at about $25-26^{\circ} \mathrm{C}$. Again, belemnites provide relatively constant and significantly cooler Aptian SSTs ${ }^{46}$, an observation that may be explained both by the habitat depth and migration pattern of these free-swimming organisms (see ${ }^{25}$ for a discussion).

Comparison with open ocean SST estimates provided by TEX . $_{\text {. }}$ Early Cretaceous SST compilations based on the $\mathrm{TEX}_{86}$ paleothermometer show rather stable and warm Barremian SSTs (Early Barremian: 26-30 ${ }^{\circ} \mathrm{C}$; Late Barremian: $\left.26-32{ }^{\circ} \mathrm{C}\right)$ and a switch to extraordinary warm Aptian SSTs $\left(>35^{\circ} \mathrm{C}\right)$. Interestingly, the majority of $\mathrm{TEX}_{86}$ SST estimates overlap with or even exceed seasonal SST maxima $\left(26-34{ }^{\circ} \mathrm{C}\right)$ identified in rudist shell calcite (Fig. 3). This observation is in concert with the well-documented offset between Late Cretaceous $\mathrm{TEX}_{86}$ and planktonic $\delta^{18} \mathrm{O}$ SSTs and points to a seasonally biased $\mathrm{TEX}_{86}$ SST signal ${ }^{51,52}$. In fact, the maximum abundance of Thaumarchaeota has been reported to vary both with seasonality and depth depending on the locality studied (see ${ }^{21}$ for a review). Only two sites (Fig. 1B) representing both, a low latitude Tethyan (Cismon section; $25^{\circ} \mathrm{N}:{ }^{53}$ ) and a middle latitude southern Atlantic setting (DSDP $511 ; 49^{\circ} \mathrm{S}:{ }^{54}$ ) provide Early Aptian TEX $_{86}$ SSTs $\left(24-28^{\circ} \mathrm{C}\right)$ that agree with contemporaneous sclerochronological mean annual SST values (Fig. 3), but deviate significantly from SSTs $\left(>35^{\circ} \mathrm{C}\right)$ provided by other $\mathrm{TEX}_{86}$ proxy records (DSDP $398 ; 33^{\circ}$ $\left.\mathrm{N}:{ }^{.5}\right)$. Following Steinig et al. ${ }^{56}$, these observed differences in $\mathrm{TEX}_{86}$ SSTs might be caused by regionally different $\mathrm{TEX}_{86}$-temperature calibrations that either reduce (DSDP 398) or increase (Cismon) SST estimates.

The new rudist shell-based sclerochronological records are therefore essential to (1) record stratigraphically well-constrained and reliable SSTs for the late Early Cretaceous subtropics and to (2) evaluate highlyresolved $\mathrm{TEX}_{86}$ SST compilations reflecting various localities that show potential regional deviations of the $\mathrm{TEX}_{86}$-temperature relation from current global core-top calibrations ${ }^{55}$.

Evaluating SST seasonality during a phase of climate instability. Most of the Barremian-Aptian shells under study provide relatively enhanced intra-shell $\delta^{18} \mathrm{O}$ peak-to-peak amplitudes, with mean values ranging between 2.1 (Early-early Late Barremian; Early-Late Aptian) and 2.9\%o (Late Barremian, early Early Aptian). Without considering intra-annual salinity changes, these $\delta^{18} \mathrm{O}$ peak-to-peak amplitudes would translate into subtropical SST seasonalities ranging between 6.7 (onset of MBE warming) and $13.7^{\circ} \mathrm{C}$ (Late Barremian). Rudists with sclerochronological evidence for a Barremian-Aptian cooling event provide relatively enhanced seasonal SST ranges $\left(<12.2^{\circ} \mathrm{C}\right)$. This is surprising, as during the present-day icehouse stage characterized by enhanced equator-to-pole SST gradients, seasonal SST amplitudes recorded in subtropical settings are considerably lower $\left(8.5^{\circ} \mathrm{C} \text { : e.g., Northern Bahamas, } 26.7^{\circ} \mathrm{N}, 78.4^{\circ} \mathrm{W}\right)^{57}$. One explanation for the in general high SST seasonalities would be that recorded seasonal $\delta^{18} \mathrm{O}$ patterns also reflect local salinity-controlled $\delta^{18} \mathrm{O}_{\mathrm{SW}}$ changes. In a previous sclerochronological study on a Late Cretaceous subtropical elevator rudist ${ }^{58}$, the authors pointed out that the recorded seasonal amplitude of $11^{\circ} \mathrm{C}$ maybe overestimated by up to $7.5^{\circ} \mathrm{C}$ due to a seasonal $\delta^{18} \mathrm{Osw}$ fluctuation of up to $1.5 \%$. Considering the paleogeographic position of the here studied Northern Tethyan and proto-North Atlantic rudist-bearing sections in the subtropical arid belt, significant seasonal $\delta^{18} \mathrm{O}_{\mathrm{SW}}$ variations $\left(>1 \%\right.$ o) are unlikely ${ }^{27}$.

Exceptionally high $\delta^{18} \mathrm{O}$ values above the Barremian-Aptian boundary. Cross-plots of $\delta^{18} \mathrm{O}_{\text {rudist }}$ and $\mathrm{Mg} / \mathrm{Ca}$ (molar) ratios provide evidence for a strong temperature effect on the incorporation of both oxygen isotopes and Mg into rudist shell calcite. The observation of species and specimen specific regression lines (Fig. 2B) is in line with Steuber and Rauch ${ }^{30}$. One exception is a lowermost Aptian rudist shell collected from the Provence carbonate platform (F/59.6R), which shows a similar regression line slope but significantly more positive $\delta^{18} \mathrm{O}$ values (see also ${ }^{35}$ ). If $\delta^{18} \mathrm{O}_{\text {rudist }}$ values are considered to solely represent SSTs, the observed abrupt positive shift would translate into a major subtropical cooling event at around the Barremian-Aptian boundary that is characterized by a temperature drop of about $8^{\circ} \mathrm{C}$ (Fig. 3). Apart from fish teeth apatite ${ }^{48}$ recording a syn- 
chronous but less pronounced SST fall in the order of about $4{ }^{\circ} \mathrm{C}$, additional proxy-based evidence for this cooling event is currently lacking. The amplitude of the here documented SST shift as indicated by strongly enhanced $\delta^{18} \mathrm{O}_{\text {rudist }}$ values, however, might be overestimated if locally or globally acting processes such as enhanced evaporation preferentially removing ${ }^{16} \mathrm{O}$ or alternatively, enhanced removing and storage of ${ }^{16} \mathrm{O}$ in ephemeral polar and/or continental ice are considered. A strongly evaporative setting is unlikely, however, as it is expected to result in significant biotic changes (e.g., monospecific assemblages of biota adapted to hypersaline conditions), which haven't been observed in the rudist bearing platform carbonates ${ }^{35,59}$. The possible existence of Early Cretaceous polar ice has been debated for decades (e.g., ${ }^{10}$ ). Modelling studies show that ice growth during the Aptian might have been possible ${ }^{60}$. Indeed, Al-Husseini et al. ${ }^{61}$ interpreted the well documented and widespread loss of shallow water carbonate platforms at the Barremian-Aptian boundary as indirect evidence for a short term $(\sim 800 \mathrm{kyr})$ glaciation event, although the proposed sea-level fall $(>30 \mathrm{~m})$ does not mutually exclude other factors. Still, the difference between the observed positive oxygen-isotope anomaly and pre-OAE1a values of about $2 \%$ is hard to explain simply by ice growth, if compared with the glacial-interglacial change in deep-sea $\delta^{18} \mathrm{O}$ of about $1 \%$ since the (Pleistocene) Last Glacial Maximum ${ }^{62}$. Modelled Cretaceous sea surface water oxygenisotope maps ${ }^{63}$, however, nicely illustrate the variability of $\delta^{18}$ Osw in the Tethyan and proto-North Atlantic shallow water realm, which is also governed by the local paleogeographic and bathymetric setting.

In order to evaluate the cooling episode postulated here and the potential growth of ice sheets around the Barremian-Aptian boundary, additional sclerochemical results from stratigraphically well-constrained carbonate platform sections are essential. If available, these (seasonally resolved) data will allow a unique insight into a tipping point of the Cretaceous climatic evolution, in particular if combined with additional independent palaeotemperature proxies such as clumped isotopes. The latter proxy will furthermore allow reconstructing seasonal $\delta^{18} \mathrm{O}_{\mathrm{SW}}$ variations and thereby testing the seasonal range of SSTs depicted by $\delta^{18} \mathrm{O}$ values in rudist shells.

\section{Material and methods}

Sclerochemistry. The outer fibrous low-Mg calcite shell layers of 23 well-preserved rudists were analyzed for ontogenetic variations in $\delta^{18} \mathrm{O}, \delta^{13} \mathrm{C}$ and major and trace element ( $\mathrm{Ca}, \mathrm{Mg}, \mathrm{Sr}, \mathrm{Fe}$ and $\mathrm{Mn}$ ) contents. Sclerochronological sampling along cross sections (number of subsamples: 13 to 80; mean: 40; s.d.: 17) followed the maximum growth axis of the shell. As elemental geochemistry requires a relatively large amount of powdered carbonate, some sclerochronological profiles could only be sampled at a relatively low resolution. As these lowresolution profiles would have likely captured a lower seasonal range of $\delta^{18} \mathrm{O}_{\text {rudist }}$ values, additional high-resolution profiles of contemporaneous shells were produced. Occasionally, the limited size of analyzed shell transects hampered the assessment of more than one $\delta^{18} \mathrm{O}$ cycle. In this case, sclerochronological profiles of several rudist fragments derived from the same stratigraphic level were compiled in order to faithfully evaluate seasonal $\delta^{18} \mathrm{O}$ patterns. In general, only oxygen isotope values of identified individual seasonal $\delta^{18} \mathrm{O}$ cycles were used to calculate sclerochronological mean, minimal and maximal values.

Carbonate powder samples were extracted from carbonate slabs by means of a hand-held PROXXON IBS/E drill equipped with tungsten carbide drill bits. In order to avoid shell portions that are affected by bioerosion or diagenetic calcite material, sampling was performed under a binocular microscope. Stable isotope analysis of 892 samples was performed at the isotope laboratory of the Institute of Geology at Leibniz University Hannover, Germany, using a Thermo Fisher Scientific Gasbench II carbonate device connected to a Thermo Fisher Scientific Delta 5 Advantage isotope ratio mass spectrometer. Samples are treated with viscous water-free $\left(98 \mathrm{~g} \mathrm{~mol}^{-1}\right)$ orthophosphoric acid at $72{ }^{\circ} \mathrm{C}$ to release $\mathrm{CO}_{2}$ of the calcite $1 \mathrm{~h}$ before the start of the measurement. Repeated analyses of certified carbonate standards (National Bureau of Standards (NBS) 19: $\delta^{13} \mathrm{C} / \delta^{18} \mathrm{O}=1.95 /-2.2$; International Atomic Energy Agency (IAEA) CO- $1: \delta^{13} \mathrm{C} / \delta^{18} \mathrm{O}=2.492 /-2.4$; IAEA CO-8: $\delta^{13} \mathrm{C} / \delta^{18} \mathrm{O}=-5.764 /-22.71$ ) show an external reproducibility (standard deviation) of $\leq 0.06 \%$ for $\delta^{13} \mathrm{C}$ and $\leq 0.08 \%$ o for $\delta^{18} \mathrm{O}$. Values are expressed in conventional delta notation relative to the Vienna-Pee Dee Formation belemnite (VPDB) international standard, in parts per mil (\%o).

$$
\delta^{18} \mathrm{O}=\left({ }^{18} \mathrm{O} /{ }^{16} \mathrm{O}_{\text {sample }} /{ }^{18} \mathrm{O} /{ }^{16} \mathrm{O}_{\text {standard }}-1\right) * 1000
$$

Aliquots of 142 powdered rudist samples (1.35-1.65 mg) were analyzed for their elemental composition using inductively coupled plasma-atomic emission spectrometry (ICP-AES) at the isotope laboratory of the Institute of Geology, Mineralogy and Geophysics at Ruhr-University Bochum (RUB), Germany. Selected samples with low manganese concentrations (threshold value of $<100 \mathrm{ppm}$ ) and high strontium concentrations (threshold value of $>800 \mathrm{ppm})$ were analyzed at RUB for their strontium-isotope ratios $(n=5)$ using a thermal ionization mass-spectrometer (Finnigan MAT 262) in dynamic mode. Corrections of measured strontium-isotope ratios to a USGS EN-1 value of 0.709175 (rather than to NIST SRM987) were done following the procedure of Howarth and McArthur ${ }^{64}$.

Oxygen isotope palaeothermometry. Oxygen isotope palaeothermometry builds on the temperaturedependent oxygen isotope fractionation between $\mathrm{CaCO}_{3}$ and water ${ }^{65-68}$. Its application to (marine) bivalve shells requires knowledge of the oxygen isotope composition of the carbonate precipitating body fluid, which is thought to be in equilibrium with ambient sea water $\left(\delta^{18} \mathrm{Osw}\right)^{68}$. In order to account for latitudinal differences in evaporation and precipitation (i.e., salinity) leading to substantial meridional $\delta^{18} \mathrm{O}_{\mathrm{SW}}$ gradients ${ }^{63,69-71}$, $\delta^{18} \mathrm{O}_{\mathrm{SW}}$ values were adjusted to salinity following the modelled mid-Cretaceous latitudinal $\delta^{18} \mathrm{O}_{\mathrm{SW}}$ distribution of Poulsen et al. ${ }^{69}$. Sea surface temperatures (SSTs) are calculated by using the equation of Anderson and Arthur ${ }^{72}$.

$$
\mathrm{T}^{\circ} \mathrm{C}=16.0-4.14 *\left(\delta^{18} \mathrm{O}_{\text {calcite }}-\delta^{18} \mathrm{O}_{\mathrm{SW}}\right)+0.13 *\left(\delta^{18} \mathrm{O}_{\text {caclite }}-\delta^{18} \mathrm{O}_{\mathrm{SW}}\right)^{2}
$$


$\delta^{18} \mathrm{O}_{\text {SW }}$ values range between -0.91 and $-0.55 \%$ and thus produce SST estimates that are $0.4-2.1{ }^{\circ} \mathrm{C}$ warmer than those based on a uniform $\delta^{18} \mathrm{O}_{\mathrm{SW}}(\mathrm{SMOW})$ of $-1 \%{ }^{73}$.

Stratigraphic framework. The integrated strontium and carbon isotope stratigraphic framework presented here is compiled from previous work $^{34-37}$ and in part complemented by additional strontium isotope measurements. We do not transfer ${ }^{87} \mathrm{Sr} /{ }^{86} \mathrm{Sr}$ values recorded by rudist shells into numerical ages based on the look-up table (version 4: 08/2003) of McArthur et al. ${ }^{40}$, as the LOWESS curve is a bimodal fit of ${ }^{87} \mathrm{Sr} /{ }^{86} \mathrm{Sr}$ values derived from a lot of different sources and environments. In contrast, superimposed stratigraphic trends of ${ }^{87} \mathrm{Sr} /{ }^{86} \mathrm{Sr}$ values and biostratigraphic markers are used to identify a stratigraphic age range. Subsequently, a more robust time control and outstanding resolution is achieved by a carbon-isotope chemostratigraphic correlation of considered rudist-bearing shallow water sections with Tethyan pelagic successions (GTS2012 time scale) ${ }^{74-76}$ (SI Appendix, Figures S1-S4).

Received: 26 February 2021; Accepted: 20 September 2021

Published online: 05 October 2021

\section{References}

1. Haywood, M. et al. What can palaeoclimate modelling do for you?. Earth Syst. Environ. 3, 1-18 (2019).

2. Tierney, J. E. et al. Past climates inform our future. Science 370, eaay3701 (2020).

3. Barron, E. J. A warm, equable Cretaceous: The nature of the problem. Earth Sci. Rev. 19, 305-338 (1983).

4. Mutterlose, J., Bottini, C., Schouten, S. \& Sinninghe Damsté, J. S. High sea-surface temperatures during the early Aptian Oceanic Anoxic Event 1a in the Boreal Realm. Geology 42, 439-442 (2014).

5. Friedrich, O., Norris, R. D. \& Erbacher, J. Evolution of middle to late Cretaceous oceans-A 55 m.y. record of Earth's temperature and carbon cycle. Geology 40,107-110 (2012).

6. O'Brien, C. L. et al. Cretaceous sea-surface temperature evolution: Constraints from $\mathrm{TEX}_{86}$ and planktonic foraminiferal oxygen isotopes. Earth-Sci. Rev. 172, 224-247 (2017).

7. Huber, B. T., MacLeod, K. G., Watkins, D. K. \& Coffin, M. F. The rise and fall of the Cretaceous hot greenhouse climate. Glob. Planet. Change 167, 1-23 (2018).

8. Gale, A. S. \& Christensen, W. K. Occurrence of the belemnite Actinocamax plenus in the Cenomanian of SE France and its significance. Bull. Geol. Soc. Den. 43, 68-77 (1996).

9. Stoll, H. M. \& Schrag, D. P. Evidence for glacial control of rapid sea-level changes in the Early Cretaceous. Science 272, 1771-1774 (1996).

10. Price, G. D. The evidence and implications of polar ice during the Mesozoic. Earth Sci. Rev. 48, 183-210 (1999).

11. Miller, K. G. et al. Late cretaceous chronology of large, rapid sea-level changes: Glacioeustasy during the greenhouse world. Geology 31, 585-588 (2003).

12. Voigt, S., Gale, A. S. \& Flögel, S. Midlatitude shelf seas in the Cenomanian-Turonian greenhouse world: Temperature evolution and North Atlantic circulation. Paleoceanography 19, PA4020 (2004).

13. Bornemann, A. et al. Isotopic evidence for glaciation during the Cretaceous supergreenhouse. Science 319, 189-192 (2008)

14. Mutterlose, J., Bornemann, A. \& Herrle, J. The Aptian-Albian cold snap: Evidence for "mid" Cretaceous icehouse interludes. Neues Jahrbuch für Geologie und Paläontologie-Abhandlungen 252, 217-225 (2009).

15. Maurer, F. et al. Late Aptian long-lived glacio-eustatic lowstand recorded on the Arabian Plate. Terra Nova 25, 87-94 (2013).

16. McAnena, A. et al. Atlantic cooling associated with a marine biotic crisis during the mid-Cretaceous period. Nat. Geosci. 6, 558-561 (2013).

17. Erbacher, J., Huber, B. T., Norris, R. D. \& Markey, M. Increased thermohaline stratification as a possible cause for an ocean anoxic event in the Cretaceous period. Nature 409, 325-327 (2001).

18. Schouten, S., Hopmans, E. C., Schefuß, E. \& Sinninghe Damsté, J. S. Distributional variations in marine crenarchaeotal membrane lipids: A new tool for reconstructing ancient sea water temperatures?. Earth Planet. Sci. Lett. 204, 265-274 (2002).

19. Wilson, P. A., Norris, R. D. \& Cooper, M. J. Testing the Cretaceous greenhouse hypothesis using glassy foraminiferal calcite from the core of the Turonian tropics on Demerara Rise. Geology 30, 607-610 (2002).

20. Pearson, P. N. Oxygen isotopes in foraminifera: Overview and historical review. Paleontol. Soc. Pap. 18, 1-38 (2012).

21. Schouten, S., Hopmans, E. C. \& Sinninghe Damsté, J. S. The organic geochemistry of glycerol dialkyl glycerol tetraether lipids: A review. Org. Geochem. 54, 19-61 (2013).

22. MacLeod, K. G., Huber, B. T., Berrocoso, Á. J. \& Wendler, I. A stable and hot Turonian without glacial $\delta^{18} \mathrm{O}$ excursions is indicated by exquisitely preserved Tanzanian foraminifera. Geology 41, 1083-1086 (2013).

23. Dutton, A., Huber, B. T., Lohmann, K. C. \& Zinsmeister, W. J. High-resolution stable isotope profiles of a dimitobelid belemnite: Implications for paleodepth habitat and late Maastrichtian climate seasonality. Palaios 22, 642-650 (2007).

24. Price, G. D., Fözy, I., Janssen, N. M. M. \& Palfy, J. Late Valanginian-Barremian (early cretaceous) palaeotemperatures inferred from belemnite stable isotope and $\mathrm{mg} / \mathrm{Ca}$ ratios from Bersek quarry (Gerecse Mountains, Trandanubian range, Hungary). Palaeogeogr. Palaeoclimatol. Palaeoecol. 305, 1-9 (2011).

25. Hoffmann, R. \& Stevens, K. The palaeobiology of belemnites-Foundation for the interpretation of rostrum geochemistry. Biol. Rev. 95, 94-123 (2020).

26. Steuber, T. Stable isotope sclerochronology of rudist bivalves: Growth rates and Late Cretaceous seasonality. Geology 24, 315-318 (1996).

27. Steuber, T., Rauch, M., Masse, J. P., Graaf, J. \& Malkoč, M. Low-latitude seasonality of Cretaceous temperatures in warm and cold episodes. Nature 437, 1341-1344 (2005).

28. Winter, De. et al. Tropical seasonality in the late Campanian (late Cretaceous): Comparison between multiproxy records from three bivalve taxa from Oman. Palaeogeogr. Palaeoclimatol. Palaeoecol. 485, 740-760 (2017).

29. Steuber, T. Isotopic and chemical intra-shell variations in low-Mg calcite of rudist bivalves (Mollusca-Hippuritacea): Disequilibrium fractionations and Late Cretaceous seasonality. Int. J. Earth Sci. 88, 551-570 (1999).

30. Steuber, T. \& Rauch, M. Evolution of the $\mathrm{Mg} / \mathrm{Ca}$ ratio of Cretaceous seawater: Implications from the composition of biological low-Mg calcite. Mar. Geol. 217, 199-213 (2005).

31. Gillikin, D. P., Wanamaker, A. D. \& Andrus, C. F. T. Chemical sclerochronology. Chem. Geol. 526, 1-6 (2019).

32. van Hinsbergen, D. J. et al. A paleolatitude calculator for paleoclimate studies. PLoS ONE 10, 1-21 (2015).

33. Skelton, P. W. \& Gili, E. Rudists and carbonate platforms in the Aptian: A case study on biotic interactions with ocean chemistry and climate. Sedimentology 59, 81-117 (2012). 
34. Huck, S., Heimhofer, U., Rameil, N., Bodin, S. \& Immenhauser, A. Strontium and carbon-isotope chronostratigraphy of Barremian-Aptian shoal-water carbonates: Northern Tethyan platform drowning predates OAE1a. Earth Planet. Sci. Lett. 304, 547-558 (2011).

35. Huck, S. \& Heimhofer, U. Improving shallow-water carbonate chemostratigraphy by means of rudist bivalve sclerochemistry. Geochem. Geophys. Geosyst. 16, 3111-3128 (2015).

36. Huck, S. et al. Latitudinally different responses of Tethyan shoal-water carbonate systems to the Early Aptian oceanic anoxic event (OAE 1a). Sedimentology 57, 1585-1614 (2010).

37. Huck, S., Heimhofer, U. \& Immenhauser, A. Early Aptian algal bloom in a neritic proto-North Atlantic setting: Harbinger of global change related to OAE1a?. GSA Bull. 124, 1810-1825 (2012).

38. Menegatti, A. P. et al. High-resolution $\delta^{13} \mathrm{C}$ stratigraphy through the early Aptian "Livello Selli" of the Alpine Tethys. Paleoceanography 13, 530-545 (1998).

39. Klein, R. T., Lohmann, K. C. \& Thayer, C. W. Bivalve skeletons record sea-surface temperature and $\delta^{18} \mathrm{O}$ via $\mathrm{Mg} / \mathrm{Ca}$ and ${ }^{18} \mathrm{O} /{ }^{16} \mathrm{O}$ ratios. Geology 24, 415-418 (1996).

40. McArthur, J. M., Howarth, R. J. \& Bailey, T. R. Strontium isotope stratigraphy: LOWESS version 3: Best fit to the marine Sr-isotope curve for 0-509 Ma and accompanying look-up table for deriving numerical age. J. Geol. 109, 155-170 (2001).

41. Jones, D. S. \& Quitmyer, I. R. Marking time with bivalve shells: Oxygen isotopes and season of annual increment formation. Palaios 11, 340-346 (1996).

42. Goodwin, D. H., Schoene, B. R. \& Dettman, D. L. Resolution and fidelity of oxygen isotopes as paleotemperature proxies in bivalve mollusk shells: Models and observations. Palaios 18, 110-125 (2003).

43. Freitas, P., Clarke, L. J., Kennedy, H., Richardson, C. \& Abrantes, F. $\mathrm{Mg} / \mathrm{Ca}, \mathrm{Sr} / \mathrm{Ca}$, and stable-isotope $\left(\delta^{18} \mathrm{O}\right.$ and $\left.\delta^{13} \mathrm{C}\right)$ ratio profiles from the fan mussel Pinna nobilis: Seasonal records and temperature relationships. Geochem. Geophys. Geosyst. 6, Q04D14 (2005).

44. Sprovieri, M., Coccioni, R., Lirer, F., Pelosi, N. \& Lozar, F. Orbital tuning of a lower Cretaceous composite record (Maiolica Formation, central Italy). Paleoceanography 21, PA4212 (2006).

45. Malkoč, M. \& Mutterlose, J. The early Barremian warm pulse and the late Barremian cooling: A high-resolution geochemical record of the Boreal Realm. Palaios 25, 13-22 (2010).

46. Bodin, S., Meissner, P., Janssen, N. M. M., Steuber, T. \& Mutterlose, J. Large igneous provinces and organic carbon burial: Controls on global temperature and continental weathering during the Early Cretaceous. Glob. Planet. Change 133, 238-253 (2015).

47. Wilson, M. E. J. Equatorial carbonates: An earth systems approach. Sedimentology 59, 1-31 (2012).

48. Pucéat, E. et al. Thermal evolution of Cretaceous Tethyan marine waters inferred from oxygen isotope composition of fish tooth enamels. Paleoceanography 18, 1029 (2003).

49. Kuhnt, W., Holbourn, A. \& Moullade, M. Transient global cooling at the onset of early Aptian oceanic anoxic event (OAE) 1a. Geology 39, 323-326 (2011).

50. Jenkyns, H. C. Transient cooling episodes during Cretaceous Oceanic Anoxic Events with special reference to OAE 1a (Early Aptian). Philos. Trans. R. Soc. A 376, 20170073 (2018).

51. Leider, A., Hinrichs, K.-U., Mollenhauer, G. \& Versteegh, G. J. Core-top calibration of the lipid-based $\mathrm{U}^{\mathrm{K}^{\prime}}{ }_{37}$ and $\mathrm{TEX}_{86}$ temperature proxies on the southern Italian shelf (SW Adriatic Sea, Gulf of Taranto). Earth Planet. Sci. Lett. 300, 112-124 (2010).

52. Qin, W. et al. Confounding effects of oxygen and temperature on the $\mathrm{TEX}_{86}$ signature of marine Thaumarchaeota. Proc. Natl. Acad. Sci. U. S. A. 112, 10979-10984 (2015).

53. Bottini, C. et al. Climate variability and ocean fertility during the Aptian stage. Clim. Past 11, 383-402 (2015).

54. Jenkyns, H. C., Schouten-Huibers, L., Schouten, S. \& Sinninghe Damsté, J. S. Warm Middle Jurassic-Early Cretaceous high-latitude sea-surface temperatures from the Southern Ocean. Clim. Past 8, 215-226 (2012).

55. Naafs, B. D. A. \& Pancost, R. D. Sea-surface temperature evolution across Aptian Oceanic Anoxic Event 1a. Geology 44, 959-962 (2016).

56. Steinig, S. et al. Evidence for a regional warm bias in the Early Cretaceous TEX $\mathrm{X}_{86}$ record. Earth Planet. Sci. Lett. 539, 116184 (2020).

57. Chollett, I., Müller-Karger, F. E., Heron, S. F., Skirving, W. \& Mumby, P. J. Seasonal and spatial heterogeneity of recent sea surface temperature trends in the Caribbean Sea and southeast Gulf of Mexico. Mar. Pollut. Bull. 64, 956-965 (2012).

58. Walliser, E. O. \& Schöne, B. R. Paleoceanography of the Late Cretaceous northwestern Tethys Ocean: Seasonal upwelling or steady thermocline?. PLoS ONE 15, e0238040 (2020).

59. Fenerci-Masse, M., Masse, J. P. \& Pernarcic, E. Quantitative stratigraphy of rudist limestones and its bearing on spatial organization of rudist communities: The Late Barremian, Urgonian, sequences of Provence (S. E. France). Palaeogeogr. Palaeoclimatol. Palaeoecol. 215, 265-284 (2005).

60. Ladant, J. B. \& Donnadieu, Y. Paleogeographic regulation of glacial events during the Cretaceous supergreenhouse. Nat. Commun. 7, 12771 (2016).

61. Al-Husseini, M. I. \& Matthews, R. K. Tuning Late Barremian-Aptian Arabian Plate and global sequences with orbital periods. In Barremian-Aptian Stratigraphy and Hydrocarbon Habitat of the Eastern Arabian Plate (eds van Buchem, F. S. P. et al.) 199-228 (Gulf Petro Link, 2010).

62. Schrag, D. P. et al. The oxygen isotopic composition of seawater during the Last Glacial Maximum. Quat. Sci. Rev. 21, 331-342 (2002).

63. LeGrande, A. N. \& Schmidt, G. A. Global gridded data set of the oxygen isotopic composition in seawater. Geophys. Res. Lett. 33, L12604 (2006).

64. Howarth, R. J. \& McArthur, J. M. Statistics for strontium isotope stratigraphy: A robust LOWESS fit to the marine Sr-isotope curve for 0 to $206 \mathrm{Ma}$, with look-up table for derivation of numeric age. J. Geol. 105, 441-456 (1997).

65. Urey, H. C. The thermodynamic properties of isotopic substances. J. Chem. Soc. Lond. 85, 562-581 (1947).

66. McCrea, J. M. On the isotopic chemistry of carbonates and a paleotemperature scale. J. Chem. Phys. 18, 849-857 (1950).

67. Urey, H. C., Lowenstam, H. A., Epstein, S. \& McKinney, C. R. Measurement of paleotemperatures and temperatures of the Upper Cretaceous of England, Denmark and the southeastern United States. GSA Bull. 62, 399-416 (1951).

68. Epstein, S., Buchsbaum, R., Lowenstam, H. A. \& Urey, H. C. Revised carbonate-water isotopic temperature scale. Bull. Geol. Soc. Am. 64, 1315-1325 (1953).

69. Poulsen, C. J., Barron, E. J., Peterson, W. H. \& Wilson, P. A. A reinterpretation of mid-Cretaceous shallow marine temperatures through model-data comparison. Paleoceanography 14, 679-697 (1999).

70. Roche, D. M., Donnadieu, Y., Pucéat, E. \& Paillard, D. Effect of changes in $\delta^{18} \mathrm{O}$ content of the surface ocean on estimated sea surface temperatures in past warm climate. Paleoceanography 21, PA2023 (2006).

71. Zhou, J., Poulsen, C. J., Pollard, D. \& White, T. S. Simulation of modern and middle Cretaceous marine $\delta^{18} \mathrm{O}$ with an oceanatmosphere general circulation model. Paleoceanography 23, PA3223 (2008).

72. Anderson, T. F. \& Arthur, M. A. Stable isotopes of oxygen and carbon and their application to sedimentologic and paleoenvironmental problems. In Stable Isotopes in Sedimentary Geology (eds Arthur, M. A. et al.) 1-151 (SEPM Short Course 10, 1983).

73. Shackleton, N. J. \& Kennett, J. P. Paleotemperature history of the Cenozoic and the initiation of Antarctic glaciation: Oxygen and carbon isotope analysis in DSDP Sites 277, 279, and 280. In Initial Reports of the Deep-Sea Drilling Project 29 (eds Kennett, J. P. et al.) 743-755 (U.S. Government Printing Office, 1975).

74. Ogg, J. G. \& Hinnov, L. A. Cretaceous. In The Geologic Time Scale 2012 (eds Gradstein, F. M. et al.) 793-853 (Elsevier, 2012). 
75. Godet, A. et al. Evolution of the marine stable carbon isotope record during the early Cretaceous: A focus on the late Hauterivian and Barremian in the Tethyan realm. Earth Planet. Sci. Lett. 242, 254-271 (2006).

76. Westermann, S. et al. Rapid changes in the redox conditions of the western Tethys Ocean during the early Aptian oceanic anoxic event. Geochim. Cosmochim. Acta 121, 467-486 (2013).

\section{Acknowledgements}

We thank Christiane Wenske (Leibniz University Hannover, stable isotope analysis) for laboratory assistance and Fritz-Lukas Stoepke (Leibniz University Hannover) for thin-section preparation. Furthermore, we would like to thank Niels de Winter and an anonymous reviewer for their critical comments and constructive contributions.

\section{Author contributions}

S.H.: Collection and petrographic and chemical analysis of shell materials. Data interpretation. Main author of manuscript. U.H.: Data interpretation and co-author of the manuscript.

\section{Funding}

Open Access funding enabled and organized by Projekt DEAL.

\section{Competing interests}

The authors declare no competing interests.

\section{Additional information}

Supplementary Information The online version contains supplementary material available at https://doi.org/ 10.1038/s41598-021-99094-2.

Correspondence and requests for materials should be addressed to S.H.

Reprints and permissions information is available at www.nature.com/reprints.

Publisher's note Springer Nature remains neutral with regard to jurisdictional claims in published maps and institutional affiliations.

(c) (i) Open Access This article is licensed under a Creative Commons Attribution 4.0 International License, which permits use, sharing, adaptation, distribution and reproduction in any medium or format, as long as you give appropriate credit to the original author(s) and the source, provide a link to the Creative Commons licence, and indicate if changes were made. The images or other third party material in this article are included in the article's Creative Commons licence, unless indicated otherwise in a credit line to the material. If material is not included in the article's Creative Commons licence and your intended use is not permitted by statutory regulation or exceeds the permitted use, you will need to obtain permission directly from the copyright holder. To view a copy of this licence, visit http://creativecommons.org/licenses/by/4.0/.

(C) The Author(s) 2021 